\title{
THE ROLES OF PRODUCTIVE ASSETS QUALITY IN MEDIATING EFFECT OF RISK MANAGEMENT IMPLEMENTATION TO THE FIRM VALUE IN INDONESIAN BANKING
}

\author{
Niswah Baroroh ${ }^{*}$ \\ Universitas Negeri Semarang
}

\begin{abstract}
This study aims to examine the role of productive assets quality in mediating the effect of risk management implementation to the firm value. The population in this study was banking that went public in Indonesia in the year 2011-2013 as many as 31 companies. This study used quantitative approach with purposive sampling technique and obtained 53 samples that met the criteria. The analysis technique used path analysis with software tools SPSS 21 . The results of this study indicated that the implementation of Risk Management and quality of productive assets did not affect the firm value. Risk Management also did not affect the quality of productive assets, and the quality of productive assets was not able to mediate the implementation of risk management to the firm value.
\end{abstract}

Keywords: Risk Management; productive asset quality; firm value

\section{INTRODUCTION}

Risk management becomes topic of current interest, related to the increasing number of uncertainties, whether caused by economic or global conditions. Investors not only need a high level of return, but also the certainty of the security funds provided. Hanafi (2012) mentions that on new view, the relationship between the risk and the profit rate is not linear, if the risk taken by the company is too small, corporate profit is also too small. However, risk taking that too high is also not able to provide high advantages with the risk taken. Therefore, companies need to optimize the risks taken so as to provide optimum return anyway. In accordance with the law of demand and supply, rise and fall of the firm value is also determined by the interest of investors to buy or sell company stock. One factor in determining this choice is the certainty of the company's survival and return level of funds already invested. Investors will certainly choose investments with higher returns and same risk level, or choose the same return with lower risk level.

The purpose of this study is to analyze the role of productive assets quality which is a part of company performance and proxied in Non-Performing Loan in mediating the effect of risk management implementation to the firm value that is proxied in price to book value. Return and risk considerations have become a choice for investors and external parties in evaluating a company. Hoyt \& Liebenberg (2011) finds that the implementation of Risk Management has positive effect to the firm value. Risk Management contributes approximately $3.6 \%$ in shaping the firm value. In the insurance companies, the firm value reaches $6 \%$ higher than those who do not apply it. Similarly, (Lai \& Samad, 2010) finds that with the ability of management in finding non-systematic risk through risk management programs will reduce costs of financial distress and external cost, improve credit rating, achieve award in the capital markets and reduce 
The Roles Of Productive Assets Quality In Mediating Effect Of Risk Management Implementation To The Firm Value In Indonesia Banking Niswah Baroroh

information asymmetries associated with agency problems, all of which lead to an escalation of firm value in order to maximize shareholder value. Different results found by (Agustina \& Baroroh, 2016), which states that there is no effect of risk management implementation to the firm value. Tahir (2011) also finds that there is no significant difference of firm values between the company which is implementing or not implementing risk management in it.

\section{H1 : Implementation of Risk Management Affects to the Firm Value}

The diversity of the findings above supported by various testing results were quite varied related to the relationship between company's performance and firm values, among others by Mahendra (2011), who reveals financial performance can effect firm value significantly, because high company's performance means that it has guarantee of high profits division. On the other hand, (Hermawan \& Mafulah, 2014) states that financial performance does not have effect to the value of the company. Similarly, Tahir (2011) said that profitability is a ratio that tends to be quiet, only applied by the time, so that its existence could not influence Tobin's Q significantly, further Tahir said that sustainability ratios felt tends to be able to influence the firm value continuously.

\section{H2: Quality of Productive Assets affects to the Firm Value}

As disclosed by (Fisher, 1993) in his contingent theory that in certain cases it is possible there are factors beyond the two variables that bridge the relationship between these two. By the grounds that company's ability in managing the risk has an impact to the quality of productive asset, so that this research tries to modify the previous studies with the originality of intervening variable of productive assets quality, as security for company's assets that bridges the effect of Risk Management Implementation to the firm value.

H3: The Quality of Productive Asset is able to mediate the effect between risk management implementation to the firm value.

The framework of this study can be illustrated in the following figure:

$\mathrm{H} 4$

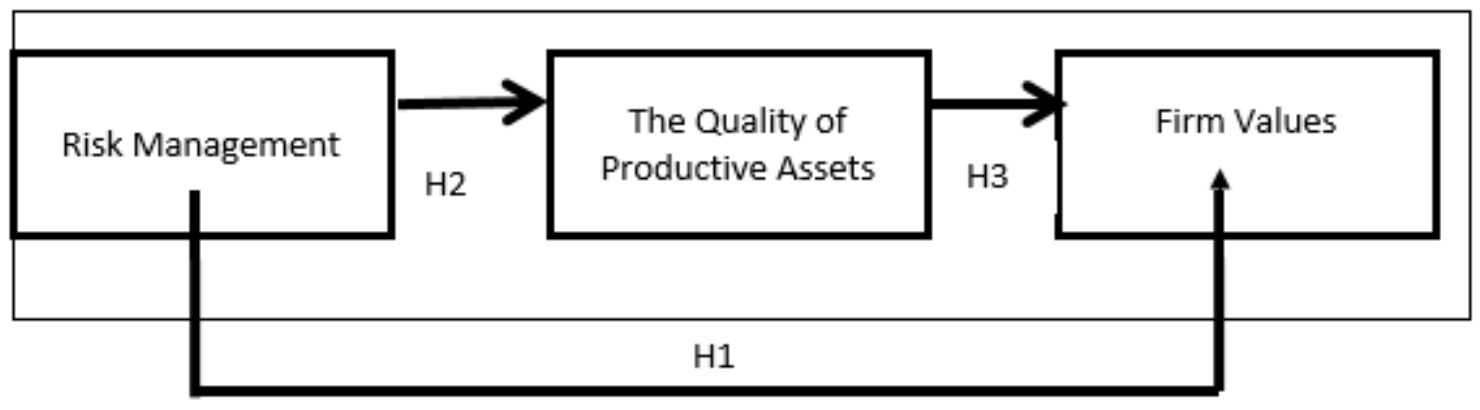

Figure 1. Framework 


\section{METHODS}

This research was a causality research, a research that measures the relationship between research variables. This study tried to prove empirically causal relationship between the Implementation of Risk Management, the Quality of Productive Assets and Firm values. This study used quantitative approach. The data used can be measured by a numerical scale (number) (Kuncoro: 2009). Risk Management used interval scale, whereas financial performance and firm values used ratio scale. Population of this study was banking companies listed in Indonesia Stock Exchange. The technique of sample selection used putposive sampling method with sample numbered 53 annual reports. Annual report in 2011 and 2012 were as the data of risk management implementation and financial performance, while data of ICMD in 2012 and 2013 was as the data of firm values. The process of obtaining 53 samples was through the following processes:

Table 1. RESEARCH SAMPLE ACQUISITION

\begin{tabular}{ll}
\hline Banking companies that went public and published its annual report in 2011- & 31 \\
2013 & \\
\hline Companies that had Risk Management Committee and revealed Risk & 31 \\
Management in the annual reports & $(1)$ \\
Companies which did not provide complete data & 30 \\
Samples companies & 60 \\
Number of samples Annual Report (year 2011 and 2012) and ICMD (2012- \\
2013) \\
Outlier Data & 7 \\
Research Samples & 53 \\
\hline
\end{tabular}

Source: Secondary data processed in 2014

The variables of this research consisted of firm values as dependent variable, quality of productive assets as intervening variable and the implementation of risk management as independent variable. The explanation of operating variables definition could be seen in the following table:

Table 2. DEFINITION OF OPERATING VARIABLES

\begin{tabular}{|l|l|l|}
\hline Name & Operational Definition & Indicator \\
\hline Firm Value (Y) & $\begin{array}{l}\text { Firm value is the sale value of the } \\
\text { company or grow value for the } \\
\text { shareholders }\end{array}$ & PBV $=\frac{\text { Market price per share }}{\text { Book value per share }}$ \\
\hline $\begin{array}{l}\text { Productive Asset } \\
\text { Quality (M) }\end{array}$ & $\begin{array}{l}\text { Analysis of productive assets } \\
\text { quality used to measure } \\
\text { company's ability in managing its } \\
\text { productive assets owned }\end{array}$ & $\mathrm{NPL}=\frac{\text { Non Performing Loans }}{\text { Credit Total }}$ \\
\hline $\begin{array}{l}\text { Implementation of Risk } \\
\text { Management (X) }\end{array}$ & $\begin{array}{l}\text { Risk Management is a set of } \\
\text { procedures and methodologies } \\
\text { used to identify, measure, } \\
\text { monitor and control risks arising }\end{array}$ & $\begin{array}{l}127 \text { statements items in the } \\
\text { guidelines of Risk Management } \\
\text { implementation for commercial } \\
\text { banks contained in Appendix of } \\
\text { Indonesian Bank Circular Letter No. }\end{array}$ \\
\hline
\end{tabular}


The Roles Of Productive Assets Quality In Mediating Effect Of Risk Management Implementation To The Firm Value In Indonesia Banking Niswah Baroroh

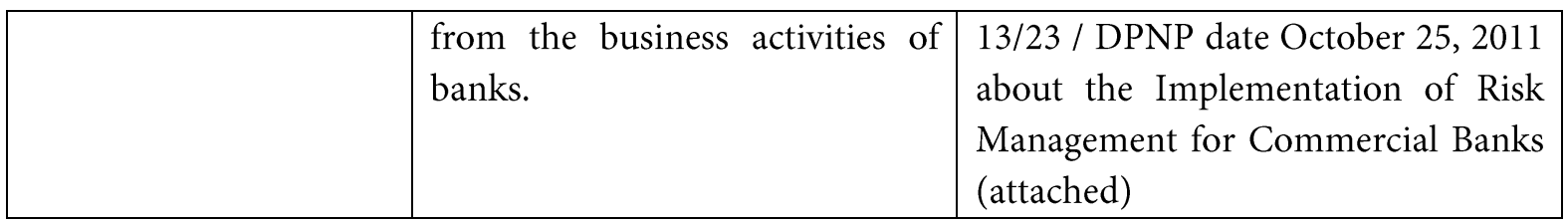

Data collection method used in this research was documentation method. Analysis of the data used was descriptive analysis, linear regression and path analysis with SPSS 21 program tools.

\section{RESULTS AND DISCUSSION}

Descriptive statistics of each variable of the research could be seen in the following table:

Table 3. VARIABLE DESCRIPTIVE STATISTICS OF THE RESEARCH

\begin{tabular}{llllll}
\hline & N & Minimum & Maximum & Mean & Std Deviation \\
\hline PBV & 53 & 0,39 & 4,57 & 1,570530 & 0,9316976 \\
NPL & 53 & 0,0014 & 0,0481 & 0,018974 & 0,0108064 \\
RISK MANAGEMENT & 53 & 28 & 118 & 79,81 & 20,168 \\
\hline
\end{tabular}

Source: Secondary data processed

From the table above, it could be concluded that average value of company stated in Price to Book Value in this study was 1.57 with a minimum value of 0.39 which was owned by BCA in 2013 and the highest value also gotten by BCA in 2012 with value of 4.57. Standard deviation was 0.9317 lower than average value amounted to 1.57 indicated that distribution variation of firm value tends to be similar to each other. Asset Quality Ratio in the proxy of Non-Performing Loan (NPL) had a standard deviation amounting to 1.08\%, lower than average value that amounting to $1.90 \%$, the data showed that the distribution was tend to approach the average value. The minimum value amounting to $0.14 \%$ was owned by PT Bank Swadesi, Tbk (BSWD) in 2012, while the maximum value amounting to $4.81 \%$ was owned by PT Bank Pundi Indonesia, Tbk (BEKS) in 2012.

The data above showed that the minimum value of Risk Management Implementation was 28 items that performed by Economic Bank (BAEK) in 2011 and maximum value amounting to 118 items performed by PT CIMB Niaga Tbk (BNGA) in 2012. Standard deviation amounting to 20.17 lower than the average value amounting TO 79.81, so it meant that the distribution of Risk Management Implementation in the sample companies was tend to approach the average value.

Hypothesis testing of this study could be seen in the following table:

Table 4. STATISTICAL TEST RESULTS OF DIRECT EFFECT

\begin{tabular}{llllll}
\hline Model & \multicolumn{2}{l}{$\begin{array}{l}\text { Unstandardized } \\
\text { Coefficients }\end{array}$} & $\begin{array}{l}\text { Standardized } \\
\text { Coefficients }\end{array}$ & t & \multirow{2}{*}{ Sig. } \\
\cline { 2 - 4 } & $\mathrm{B}$ & Std. Error & Beta & \\
\hline (Constant) & 206,249 & 52,747 & & 3,910 &, 000 \\
RISK MANAGEMENT &,- 616 &, 641 &,- 133 &,- 961 &, $341^{\mathrm{a}}$ \\
RISK MANAGEMENT &,- 008 &, 007 &,- 144 & $-1,039$ &, $304^{\mathrm{b}}$ \\
NPL & $-9,628$ & 11,997 &,- 112 &,- 802 &, $426^{\mathrm{c}}$ \\
\hline
\end{tabular}


Dependent Variable: PBV

Dependent Variable: NPL

Dependent Variable: PBV

Source: Secondary data processed

Statistical test results of risk management implementation effect to the firm value could be seen in Table 4 in which its significance level was 0.341 , greater than 0.05; so it could be concluded that $\mathbf{H 1}$ in this research was rejected. The result of this study was on the contrary to (Hoyt \& Liebenberg, 2011) and (Bertinetti, Cavezzali, \& Gardenal, 2013) who had previously found the influence of both. However, this research was similar with (Pagach \& Warr, 2010), Tahir and Razali (2011), Skerci (2013) who also found there was no significant effect of both. It was due to the implementation of risk management for banking companies was an obligation as stipulated in Bank Indonesia Regulation No. 5/8/ PBI / 2003 on Risk Management for Commercial Banks. The implementation of risk management was considered as an obligation activity for the Banks and not an effort to attract investors to owe the company.

Moreover, as revealed by Skerci (2013) that the information about risk management was qualitative that needed to be examined one by one, so that many investors were not giving more attention to this information. Lack of attention to this caused the information of risk management implementation had no significant effect to the firm value. The quality of firm productive assets closely associated with the implementation of companies ERM, primarily relating to credit risk. The existence of ERM in credit risk was primarily to provide security for investors that management has made risk management efforts as a security of company's asset quality.

Table 4 also showed that the implementation of risk management statistically had not significantly negative impact to the liquidity of the company in a proxy of Non-Performing Loan (NPL), shown with a significance level of 0.304 ; exceeding $\alpha=0,05$, so it could be concluded that $\mathbf{H 2}$ in this study was rejected. The absence of influence of these two variables caused by there was no different ranges of time in this study, whereas the detection and handling of non-performing loans might take more than one year, so the effect of them have not seen significantly because basically Management risk was a set of procedures which function to detect on the risks that may arise in the future.

The quality of productive assets was a continuous performance over time which was also an indicator of banks health level. Tahir (2011) revealed that sustainability ratio felt able to influence the firm value. Variable of productive assets quality (Non-Performing Loan) statistically was not significant at $\alpha=0.05$, which amounted to $0.426(0.426>0.05)$ shown in the table above. B value that in the amount of -9.628 indicated negative effects between these two, so it can be concluded that NPL did not have significantly negative effect to the firm value. In conclusion, $\mathrm{H} 3$ in this study was rejected.

It was caused by external parties were less concerned with the quality of productive assets as the basis for determining the assessment of the company. From the results of descriptive analysis that has been done, it seen that the average value of productive assets quality proxied in Non-Performing Loans (NPLs) in the amount of $1.90 \%$ indicated that NPL on the sample product was very good, and still far from the 
The Roles Of Productive Assets Quality In Mediating Effect Of Risk Management Implementation To The Firm Value In Indonesia Banking Niswah Baroroh requirements demanded by Bank Indonesia, in which NPL minimum standards to maintain the health of banks was maximum 5\%. The maximum value of NPL amounting to $4.81 \%$ in the study also still tend to be safe for fulfilling healthy criteria from Bank Indonesia. On the basis of the results, it could be concluded that the sample in this study tended to have a good NPL, entirely still met the banks healthy by Bank Indonesia, so the investors tended to not always focus on the quality of company's productive assets in the analysis of company's assessment.

As for the indirect effect between the implementation of risk management to the firm value through the quality of productive assets could be seen in the following table:

Table 5. STATISTICAL TEST RESULT OF INDIRECT EFFECT OF RISK MANAGEMENT TO THE FIRM VALUE THROUGH THE QUALITY OF PRODUCTIVE ASSETS

\begin{tabular}{lccccc}
\hline \multicolumn{5}{l}{ Indirect Effects of IV on DV through Proposed Mediators (ab paths) } \\
& Data & Boot & Bias & SE & t count \\
\hline NPL &, 0936 &, 0986 &, 0050 &, 1814 & 0,51598677 \\
\hline
\end{tabular}

Source: Secondary data processed in 2014

Table 5 showed $t$ value as many as 0.51598677 , it was used to see the significance of mediating variables influence of productive assets quality (Non-Performing Loan) to the variables of Implementation Risk Management and the firm value. $\mathrm{t}$ table one tail for sample numbered 53 was in the amount of 1.6741. Because $t$ count was less than $t$ table $(0.51598677<1.6741)$ it could be concluded that $\mathbf{H 4}$ in this study was rejected. It was caused by the quality of productive assets in the proxy of Non-Performing Loan (NPL) itself did not become a significant thing in the selection of the stakeholders decision. The quality of productive assets and the implementation of ERM was still considered as the fulfilment of an obligation on the Bank Indonesia regulation that required the implementation and fulfilment of NPL maximum of 5\%, so that the external parties considered both of these things not as a positive signal for making the decisions, both of them just as the information in the annual report of the company.

\section{CONCLUSIONS}

Risk Management Implementation does not have significant effect to the value of the company. It is caused partly because Risk Management Implementation is an obligation for all banks in accordance with the regulations of Bank Indonesia No. 5/8/ PBI/2003 about Risk Management for Commercial Banks, so that the implementation conducted is tend to fulfil obligations on the regulation. Moreover, as it has revealed by Skerci (2013), external parties do not put the focus more on qualitative reporting, because it would be hard to compare one with the others.

Implementation of Risk Management does not significantly influence the quality of productive assets. It is due to the implementation of risk management in the company is a form of bank compliance to existing regulations. In addition, Bank Indonesia Circular Letter no. 13/23/DPNP dated October 25, 2011 on Amendments to Circular Letter No. 5/21/DPNP concerning Implementation of Risk Management for Commercial Banks, which means the implementation done is almost identical to each other, so it does not significantly affect the performance of the company. 
The quality of productive assets could not affect the value of the company significantly. It is due to the solvency is a company's long term financial ratio, not an operational reflection of the company during the period, so it does not describe the condition of the period. The quality of productive assets could not mediate the relationship between the Implementation of Risk Management to the firm value. It was caused by the implementation of risk management in the banking sector is an attempt to meet the obligation of the bank on Bank Indonesia regulation that exists.

For further researcher, if they will develop this research, it is better to use a period of time lag-1 or lag2 for the financial performance, with the consideration that the implementation of Risk Management is an investment in the future for the company in an effort to rescue company's operations. The variable of risk management implementation can be developed through primary data, direct analysis or interviews to interested parties to obtain the data that really could describe the implementation of risk management as a whole. Researchers can be more focused on the types of non-financial companies (non-banking) relating to the obligation for banks to undertake implementation of risk management within the guidelines which

have been set, so the reporting of the implementation done in the annual reports tend to be uniform with one another, making it less able to describe the effort of risk mitigation through this risk management.

\section{REFERENCES}

Agustina, L., \& Baroroh, N. (2016). The Relationship Between Enterprise Risk Management (ERM) And Firm Value Mediated Through The Financial Performance.

Bank Indonesia. 2003. Peraturan Bank Indonesia nomor: 5/8/PBI/2003 tentang Penerapan Manajemen Risiko Bagi Bank Umum

Bertinetti, G. S., Cavezzali, E., \& Gardenal, G. (2013). The effect of the enterprise risk management implementation on the firm value of European companies.

Fisher, J. G. (1993). Contingency theory, management control systems and firm outcomes: past results and future directions. Behavioral Research in Accounting, 10, 47.

Ghozali, Imam. 2011. Aplikasi Analisis Multivariate dengan Program SPSS Cetakan IV. Semarang; Badan Penerbitan Universitas Diponegoro.

Hanafi, Mamduh. 2012. Manajemen Risiko Edisi Kedua. Yogyakarta: UPP STIM YKPN.

Hermawan, S., \& Mafulah, A. N. (2014). Pengaruh Kinerja Keuangan Terhadap Nilai Perusahaan Dengan Pengungkapan Corporate Social Responsibility Sebagai Variabel Pemoderasi. Jurnal Dinamika Akuntansi, 6(2).

Hoyt, R. E., \& Liebenberg, A. P. (2011). The value of enterprise risk management. Journal of Risk and Insurance, 78(4), 795-822.

Kuncoro, Mudrajad. 2009. Metode Riset untuk Bisnis dan Ekonomi. Edisi 3. Jakarta: Penerbit Erlangga.

Lai, F.-W., \& Samad, F. A. (2010). Enterprise risk management framework and the empirical determinants of its implementation. Risk, 6(7), 8.

Mahendra, Alfredo. 2011. Pengaruh Kinerja Keuangan terhadap Nilai Perusahaan (Kebijakan Deviden sebagai Variabel Moderating) pada Perusahaan Manufaktur di Bursa Efek Indonesia. Tesis Universitas Udayana Bali.

Nugroho, Deni Pandu. 2013. Efek Manajemen Risiko (MANAJEMEN RISIKO) Studi Empirik pada Reaksi Pasar dan Kinerja Perusahaan. Tesis Universitas Gajah Mada

Pagach, D. P., \& Warr, R. S. (2010). The effects of enterprise risk management on firm performance. 
The Roles Of Productive Assets Quality In Mediating Effect Of Risk Management Implementation To The Firm Value In Indonesia Banking Niswah Baroroh

Skerci, Naciye. 2013. Does Manajemen Risiko Create Value for Firms?: Evidence from Nordic Countries. Ph.D thesis, School of Economics and Management, Lund University.

Tahir, Izah Mohd and Ahmad Rizal Razali. 2011. “The Relationship Between Manajemen Risiko (MANAJEMEN RISIKO) and Firm Value, Evidence From Malaysian Public Listed Companies”. International Journal of Economics and Management Science, vol.1 No.2 2011, pp 32-41.

www.idx.co.id 